\title{
A STATE WITHIN THE STATE? AN EVENT STUDY ON THE BUNDESBANK
}

\author{
Helge Berger ${ }^{*}$ and Jakob de Haan ${ }^{* *}$
}

January 1997

\begin{abstract}
The Bundesbank is often regarded as a very independent central bank. Its formal independence does not imply, however, that the BuBa operates in a political vacuum. This paper analyses certain periods in the history of the Bundesbank taking into account determinants of central bank independence outlined in the literature. We conclude that many such determinants (notably public opinion and political instability) played indeed a role in the making of the Bundesbank Law of 1957. Still, it was mainly the unresolved issue of federalism that helped the Bundesbank to save its autonomy granted by the Allies in 1948. The Bundesbank and the federal government had quite a number of conflicts about monetary policy during the 1960s, which are analysed in the paper tapping various sources, including unpublished minutes of the Governing Council of the Bundesbank. It is concluded that in conflicts about interest rate policy the BuBa always got its way. Even with respect to exchange rate policy, which is primarily in the realm of the federal government, the position of the Bundesbank often prevailed. Another important conclusion is that the theory on (determinants of) central bank independence overlooks that the government and the Bundesbank were not two monolithic entities, but were often divided in themselves, which provided the Bundesbank with room of manoeuvre that it skilfully exploited.
\end{abstract}

Key words: Bundesbank, central bank independence, monetary policy

JEL-code: E58

\footnotetext{
* Center for Economic Studies, University of Munich, Germany.

** Department of Economics, University of Groningen, The Netherlands. Research for this paper started while Jakob de Haan visited the Center for Economic Studies.
} 


\section{Introduction}

Former chancellor Helmut Schmidt has recently argued that the Bundesbank seems like a state in the state. ${ }^{1}$ Still, a recent survey of a German research institute on attitudes towards public institutions reflects a high level of trust by the German population in both the Federal Constitutional Court and the Bundesbank (scoring 2.2 and 2.1, respectively, on a scale of 3) which compares favourably with the scores of the federal government (0.6) and the lower house of parliament (0.9), respectively. ${ }^{2}$ Indeed, the Bundesbank serves as an example for many countries. The German central bank is widely regarded as being very independent (Berger, 1996). At the same time, Germany has one of the best post World War II inflation records in the OECD area. This suggests that an independent central bank may be beneficial in lowering inflation. After Rogoff (1985) posed that delegation of monetary policy to a "conservative" ${ }^{3}$ and independent central banker may - at least partially - overcome the inflationary bias of monetary policy, a huge number of empirical studies have been published reporting a negative relationship between central bank independence and the rate of inflation (see Cukierman (1996) and Eijffinger and De Haan (1996) for reviews). Generally, these studies employ legal measures of central bank independence as a proxy for actual central bank independence. Recently, the inverse relationship between central bank independence and inflation has, however, come under attack.

First, the relevance of legal independence measures to test whether central bank independence is conducive to lower inflation has been disputed. For instance, Forder (1996, pp. 43-44) argues that "a central bank may be independent by statute, and it is nevertheless accepted - on all sides - that the government will have its wishes implemented. .....it is quite clear that the reading of statutes is not a measure of independence in the sense required by the theory .... There is no theory that says it matters what the rules say. There is only a theory that says it matters what the behaviour is". Of course, one could conjecture that the statutes of the central bank may (at least partially) shape the options for the central bank to pursue the kind of policies that it deems necessary. Some authors have examined whether the German central bank behaves according to the wishes of the federal government, but the results of these studies are quite mixed. Frey and Schneider (1981) conclude that the Bundesbank often gives in to the government, while Vaubel (1997) argues that the political sympathy of Council members follows the ideology of the party dominating the states (Länder) or federal government that nominates the Council member concerned. However, Berger and Woitek $(1996,1997)$ find no evidence for political business cycles or partisan influences on the use of monetary instruments in Germany.

Second, assuming that despite these criticisms legal independence is a good proxy for actual central bank independence, most research so far has not been very careful in constructing and handling these indicators. One should distinguish between various aspects of central bank independence:

independence in personnel matters, which refers to the influence that government has in appointment procedures;

- $\quad$ financial autonomy, i.e. the degree to which government is able to finance its expenditures either directly or indirectly via central bank credits;

- $\quad$ policy independence, by which we mean the room to manoeuvre apportioned to the central bank in the formulation and execution of monetary policy. Here one can discern goal independence (the central bank is free to set the final goals of monetary policy) and instrument independence (the central bank is free to choose the means by which it seeks to achieve its goals). 
De Haan (1996) shows that various measures of legal central bank independence are in fact hybrid in the sense that they both measure 'conservativeness as embodied in the law' (i.e. the degree to which the statute of the central bank defines price stability as the ultimate goal of monetary policy ${ }^{4}$ ) and legal independence. Decomposing the well known legal index of Cukierman (1992) along these aspects of (legal) independence, De Haan (1995) concludes that only instrument independence is significantly related to inflation performance. A similar conclusion has been drawn by Debelle and Fischer (1995) on the basis of the index of Grilli, Masciandaro and Tabellini (1991). Apparently, what matters most for the success of monetary policy is the degree to which the central bank is legally empowered in using its instruments. One obvious explanation is that the rules applying to instrument independence have a much more direct effect on the actual behaviour of a central bank than, for instance, appointing procedures for the governor or more or less vaguely defined policy objectives.

Third, problems regarding the coordination of economic policies may also influence the correlation between central bank independence and inflation. Whereas most theoretical models make no clear distinction between monetary and fiscal policy, other studies do concentrate on conflicts that can arise when monetary and fiscal policy are delegated to independent institutions. The government controls fiscal policy and the central bank controls monetary policy. Policymakers both set goals for the economy and choose their own priorities. The government and the central bank can either cooperate in implementing their policies or, alternatively, choose not to cooperate. Andersen and Schneider (1986) and Doyle and Weale (1994) show that in such a context having an independent central bank may not be optimal. One could, however, conjecture that an independent central bank may be beneficial for the government, since it could serve as a scapegoat in case of unfavourable economic developments and bear the political costs associated with compensating the inflationary effects of fiscal policy (Kane, 1980). As Issing (1993, p. 20) puts it: "Of course, the critique on the Bundesbank is highly correlated with the failure of other actors in the field of economic policy to secure price stability; attacks on the Bundesbank then have the function to distract from this neglect."

Finally, a negative correlation between legal central bank independence measures and inflation as reported in most empirical studies does not necessarily imply causation. The correlation between both variables could be explained by a third factor, e.g. the culture and tradition of monetary stability in a certain country. Indeed, Posen $(1993,1995)$ has challenged the conventional view on this ground, arguing that the strength of the opposition of the financial sector against inflation both determines the degree of central bank independence and the level of inflation. According to Posen monetary policy is driven by a coalition of political interests in society, because a central bank will be prepared to take a strong anti-inflation line only when there is a coalition of interests politically capable to sustain such a policy stance. In industrial countries, the financial sector represents such a coalition. This line of argument fits in with a relatively new development in the literature which seeks to explain cross-country differences in central bank independence. As will be argued in section 2, research on this very important issue has produced disappointing results so far. One important reason being that most research on the determinants of (actual) central bank independence consists of cross section estimates, while the theoretical framework on the determinants of central bank independence as developed by Cukierman (1994) refers to a time series context. Cukierman presumes that the delegation of monetary policy to (partly) independent central banks is a '(partial) commitment device.' By specifying the objectives of the central bank and by giving it certain powers, politicians determine the extent of their commitment to a policy rule. Such policy action leads to more credibility of monetary policy which, in turn, is reflected 
in lower inflationary expectations and, thereby, lower (capital market) interest rates and more moderate wage demands. From the politician's viewpoint, the costs of an independent central bank consist mainly of the loss of flexibility in monetary policymaking. The balance between flexibility and credibility, depending on the relevance of various economic and political factors to delegate authority, determines in this view the optimal degree of central bank autonomy in a country.

The present paper analyses the position of the Bundesbank on the basis of an historical account of the debate on the Bundesbankgesetz and policy conflicts between the Bundesbank and the German government. In this sense, we extend the analysis of Holtfrerich (1988), but we focus exclusively on the 1950s and 1960s. Starting point of our analysis is the theory on the determinants of central bank independence, which is briefly reviewed in the following section. The third section focuses on the debate on the Bundesbankgesetz 1957 and relates it to the theory outlined in section 2. The law has not been changed since its introduction. This fact may be interpreted differently. Either the government believed that the balance between benefits and costs of having an independent central bank did not fundamentally change, or policymakers believed that no matter what the law says, they could have their way. One possibility to examine what is the most likely explanation is to analyse in some detail the conflicts that have occurred between the Bundesbank and the government. This is done in section 4 . The final section offers some concluding comments.

\section{Determinants of central bank independence}

As pointed out above, Cukierman (1994) presumes that the balance between the advantages and the costs of having an independent central bank determines the degree of central bank autonomy deemed optimal in a country. Based on this framework, we can distinguish various factors that may affect central bank independence.

First, the average employment-motivated inflationary bias in a country may be relevant here. Cukierman (1994) shows that the larger the average employment-motivated inflationary bias in a country is, the higher are the costs for the government to override the central bank, and therefore, the more independent the central bank will be.

The stock of government debt is another potential determinant of central bank independence. The larger the sum the government wants to borrow on the capital market, the more weight is placed on lower inflationary expectations and, thus, on lower nominal capital-market interest rates. The benefits of a once-and-for-all reduction of the real value of government debt by unexpected inflation do not outweigh (in this case) the costs of permanently higher interest payments as a consequence of lower credibility (Cukierman, 1994).

A third factor suggested in the literature is political instability. It could be argued that when politicians in office are faced with a greater probability that they will be removed from office, they have a stronger interest in delegating authority to the central bank as an apolitical institution, in order to restrict the range of policy actions available to the present opposition if the latter would later come into office. This implies that greater political instability leads to a more independent central bank (Cukierman, 1994). This view of course implicitly assumes that the next government will not change the central bank statute as soon as it comes to power. In other words, there should be a minimum level of consensus about political procedures and the like among political parties. In the absence of this 
consensus, it is more likely that the incumbent politicians will fortify their hold on the central bank, if there is a greater probability of government change, and will overrule central bank decision making. Cukierman (1992) argues that it is possible to combine both hypotheses into one single, internally consistent hypothesis. In countries with a sufficiently high degree of national consensus, greater political instability may be associated with increased independence of the central bank, whereas the reverse may apply for countries with a relatively low level of national consensus.

Fourth, Posen (1993) advocates that the degree of financial opposition to inflation is a prime determinant of central bank independence. Posen asserts that monetary policy is driven by a coalition of political interests in society, because central banks will be prepared to take strong anti-inflationary actions only when there is a coalition of interests politically capable of protecting their anti-inflationary policy. In industrial countries, the financial sector represents such a (powerful) coalition of interests. In terms of Cukierman's framework, we could rephrase Posen's view as follows. The higher the effectiveness of the financial sector to mobilize its opposition against inflation, the more costly it will be for the government to have a submissive central bank.

In a similar vein, it can be argued that another important determinant of central bank independence is public support for the objective of price stability. So, if the public at large is very much opposed to inflation, the benefits for the government to have an independent central bank will exceed the costs. Issing (1993, p. 15) notes that ".... it is no coincidence that it is the Germans, with their experience of two hyperinflations in the 20th century, who have opted for an independent central bank which is committed to price stability". It should, however, be pointed out that the public opinion is not entirely exogenous. The Bundesbank tries to influence public opinion through its publications and press announcements.

So far, the empirical evidence on the factors that determine central bank independence is disappointing. For one thing, the results of various empirical studies are contradictory. Posen's empirical results have, for instance, been challenged by De Haan and Van 't Hag (1995). Only in the regression in which the legal central bank independence index of Cukierman is the dependent variable, Posen's indicators for financial opposition appear to be significant. For other indicators of central bank independence this result does not show up. Similarly, with respect to the impact of political instability the results of the research is very mixed (see Eijffinger and De Haan, 1996).

As follows from these examples, what most empirical studies do is to relate on a crosssectional basis a legal index of central bank independence to some possible explanatory variables (determinants). This is somewhat unconvincing for at least two reasons. First, it is assumed that these legal measures are proper indicators for actual central bank independence, which may not be true (see section 1). Second, most analyses are cross-sectional, to which it can be objected that they do not take into account changes over time in the balance between credibility (advantages of having an independent central bank) and flexibility (the costs of having an independent central bank). Therefore, the remainder of this paper consists of an event study on the Bundesbank in which we try to relate actual developments to the theory outlined above. We will focus on those conflicts which are relatively unknown in the literature and in which we had access to the official minutes of the meetings of the Zentralbankrat, which become only available with a lag of thirty years. 


\section{The making of the Bundesbank Law 1957}

One would perhaps expect that the Bundesbank law of 1957 was the result of a united German effort to implement national consensus on inflation policy. However, the law was born only after a long and tedious political process which outcome was, for many areas of central bank independence, not at all clear. The debate started as early as 1949, reached a height in 1951, when the provisional Übergangsgesetz brought the Bundesbank (until 1957 named Bank deutscher Länder) under German jurisdiction, and it finally peaked in 1955/56 with a major conflict between the bank and the German Chancellor about the conduct of monetary policy.

The Bundesbank was a "child of the law of the occupying forces" (Hentschel, 1988, p. 5). The Bank deutscher Länder was modeled on a federal basis, in which the central banks in the Länder were of prime importance. The first Bundesbank Law of $1948^{5}$ made the bank's decisions subject to the consent of the Allied Banking Commission, a branch of the Allied High Commission in Germany. However, there is ample evidence that the dependent legal status of the bank actually worked as an insulation against the German federal government that tried to force the Bundesbank to weaken its antiinflationary policy stance during the balance of payments crisis of 1950/51 (Berger and Ritschl, 1995). This conflict was one of the reasons why, when the Allied Banking Commission prepared to lay down its legal powers over the bank in 1951, the Minister of Finance, Fritz Schäffer (9/1949-10/1957, CSU), wanted the Bundesbank under the jurisdiction of the conservative coalition government as soon as possible. Only then, the Minister argued, the bank could be forced to finance further job creation programmes and be stopped to counteract the expansionary stance of fiscal policy (Hentschel, 1988). There was no constitutional constraint, because Article 88 of the German constitution (Grundgesetz) leaves it to parliament to define the degree of independence of the central bank. While the Grundgesetz can only be changed by $2 / 3$ of the votes, the Bundesbank law can be changed by a simple majority vote (Holtfrerich, 1989).

In the light of high German postwar unemployment Schäffer initially had the support of Chancellor Adenauer (4/1949-10/1963, CDU) and was backed by members of parliament from both the conservative parties and the social democratic opposition. However, the Bundesbank and the Minister of Economic Affairs, Ludwig Erhard (9/1949-10/1963, CDU), sharply opposed Schäffer's views. They pointed out supply-side reasons for the existing labour market difficulties and argued that giving up the independence of the central bank would only introduce an inflationary bias into monetary policy (Berger, 1995). However, what actually prevented the cabinet from passing Schäffer's proposal on to parliament was not the question of independence, but the unresolved issue of federalism. At the end of 1950 more and more legal experts, including the Minister of Legal Affairs, agreed that the provisions of the Grundgesetz were not compatible with the way the Allies had constructed the Bank deutscher Länder in 1948. Essentially, the German central bank worked as a US-type federal reserve bank system in which the German Länder held all the assets, the majority of voting rights, and divided the bank's profits among them. Seizing the opportunity, Erhard and the Bundesbank Directorate joined the centralists who fought the Schäffer proposal. The debate ended with a compromise of sorts. For the time being, a set of two laws, the provisional Transformation Law of $1951^{6}$ and the Law on Bundesbank Seigniorage ${ }^{7}$, allotted 20 percent of the bank's profits in the years 1951/52 to the central government and granted the Bundesbank a high degree of independence. Although the federal government was now allowed to participate at the Bundesbank's Council meetings, its veto power was 
restricted to suspending Council decisions for 8 days. In addition, the Bundesbank was asked to support the government's economic policy "within its duties" (Art. II 6.a Transformation Law 1951), that is, only as far as this did not collide with its primary task to "strengthen the currency" (Introduction Bundesbank Law 1948). Except for these changes the founding law of 1948 was simply prolonged. All issues, including independence, were to be reconsidered when the proper Bundesbank Law could be agreed upon.

The compromise of 1951 turned out to be more permanent than expected. As a matter of fact, the arrangements concerning independence in the final Bundesbank Law of 1957 were essentially the same as in 1951 (Berger, 1995). One relevant factor here was that the centralists were willing to grant the Bundesbank a higher degree of formal policy autonomy, provided that the federal government was guaranteed a sufficiently high influence on the appointment procedures for the bank's Council (Hentschel, 1988). The idea also had some appeal to Chancellor Adenauer. Even though Adenauer, like later Chancellor Helmut Schmidt (see Section 1), did not want the Bundesbank to act as a state within the state, he thought that, to some extent, policy independence could be substituted by personal dependence. There were, however, other determinants of the Bundesbank's status that bound Adenauer in his wish to control monetary policy. The single most important factor working in that direction was public opinion.

During the so-called Gürzenich-affair of 1955/56, a highly visible conflict between the Bundesbank and Adenauer, the Chancellor learned that the German public was strongly in favour of an autonomous central bank. The affair started when the central bank in mid 1955 raised interest rates after a long period of monetary ease (see figure 1). In a move that should later become something like a regular pattern in periods of monetary tightening, the Bundesbank combined restrictive policy measures with a critique of federal fiscal policy. Internally, the change in interest rates was labelled a "warning signal" and the bank officials made sure that the move was interpreted accordingly in the media. ${ }^{8}$ It soon became clear that the incumbent conservative coalition would enter into a huge spending spree to buy its way out of the low poll ratings before the 1957 election (Schenkluhn, 1985). ${ }^{9}$ When, as a consequence, the Bundesbank announced its intentions to further increase interest rates in March 1956, the federal government for the first time used its veto to suspend the decision for 8 days (Berger, 1995).

[insert figure 1 here]

The Bundesbank stood strong in this encounter, even though the new Bundesbank Law was still pending and the Directorate was informed about renewed government efforts to deprive it from its independent status, because it received support from within the cabinet, too. The popular Minister of Economic Affairs, Erhard, and the Minister of Finance, Schäffer, both supported a more contractionary monetary stance. Erhard viewed such a policy as necessary to restrict inflation and Schäffer wanted to save the huge funds (almost 4 percent of GDP) that he had accumulated for the German rearmament from the forces summoned by the upcoming election. Soon after the veto, the group of three started working on a plan that successfully focused the public debate on the issue of price stability being threatened by escalation and conflict. They drafted a stabilisation program to be implemented by the central government. The preparation was done very quietly and Chancellor Adenauer was caught by surprise when his ministers Erhard and Schäffer submitted the program to the cabinet in mid May 
1956. One day later, while both the media and the Chancellor were still busy checking the details of the proposal, both government members joined the Bundesbank Council meeting in Frankfurt. With the open support of the ministers, the bank raised interest rates again. The Council let no doubt that this step was a direct consequence of the bad performance of fiscal policy. There had been enough "warnings", the official minutes of the Council meeting said, now "stronger measures" were called for (Berger, 1995, p. 259).

The incident immediately received media coverage. But what really alerted the public was the angry reaction of Chancellor Adenauer (Riedl, 1992). Adenauer appeared before a meeting of the BDI, Germany's most influential industrial interest group, in the Gürzenich hall in Cologne and attacked Erhard, Schäffer and the Bundesbank. In a very aggressive manner he promised the industrialists to discipline all three and to reject further contractionary measures. He added that the independence of the central bank should have its limits when it ignored the policy guidelines set by the Chancellor (Koerfer, 1988). However, the debate provoked by the event soon made it obvious that the public disapproved. Virtually every German newspaper, the representatives of the financial sector and even small-business interest groups took the side of the Bundesbank and its allies. By the end of May 1956 the Chancellor gave in and agreed to the stabilisation program as well as to the Bundesbank's independent position. There was, however, some comfort in this outcome as well. With the public so strongly taking the side of the Bundesbank, Erhard, and Schäffer, the Chancellor could shift the responsibility for the rigid monetary policy and the additional fiscal measures to the central bank and the ministers as scapegoats. An additional reason might have been that 1956 was a particularly bad year for the incumbent government as the chances for re-election were considered to be very small at the time (Schwarz, 1991). Given the prevailing 'anti-Adenauer' majority of state representatives in the Bundesbank Council, overruling the bank would have also meant to break the system of checks and balances between the federal and the state level implicit in the existing Bundesbank laws of 1950/51. This, in turn, would also have increased the probability of a left-wing dominated central bank council after the election.

In the summer of 1956 is was more or less clear that the new law, now planned to be effective in 1957, would resemble the 1951 Transformation Law as far as the autonomy of the Bundesbank was concerned. Adenauer and the conservative majority in the parliament settled for the centralist's approach to the problem, that is, substituting greater personal dependence for policy autonomy. The new Bundesbank Law $^{10}$ allowed the Directorate, nominated directly by the government, to vote in the Council with the Presidents of the Landeszentralbanken of the German states (par. 6 and 7). The latter were downgraded to local departments of the federal central bank (par. 8). The head of the Directorate also became the (only) President of the Bundesbank, while the old law had known a double-presidency by the head of the Directorate and the President of the Council (par. 7). In addition, the bank now belonged to the federal government which also would receive seigniorage profits (par. 2). ${ }^{11}$

As could be expected, Adenauer used the changed provisions of the Bundesbank Law to appoint a new President. ${ }^{12}$ The old leadership was ready and willing to stay on, but the Chancellor wanted to make sure that the new central bank governor would re-establish the communication between Frankfurt and the head of federal government - a connection he viewed as seriously damaged by the Gürzenich-affair (Marsh, 1992). The appointee, Karl Blessing, was considered to stand closer to the industrial interest groups than his predecessors. However, Blessing had risen through the ranks of the old Reichsbank just as the former Presidents and hurried to assure the public that he would follow the same objectives, too. ${ }^{13}$ Also, Adenauer did not insist on fully exploiting the legal possibility to expand 
the Directorate to hold more than 50 percent of the votes in the Bundesbank Council (Berger, 1995). As a consequence, the central bank Council was still dominated by the same Presidents of the regional Landeszentralbanken, who had unanimously decided to raise the discount rate against the Chancellor's veto in early $1956 .{ }^{14}$ This observation reinforces the argument on checks and balances made above. Even after the election, the Chancellor honoured the role the German states played in the Bundesbank Council since 1948 in order to prevent single-party dominance of the Council in the future. Doing so, he could rely on a national consensus that secured a proportional representation of parties in similar German institutions (e.g. the Federal Constitutional Court) as well.

In the light of the discussion of central bank independence reviewed in section 2, it can be concluded that the issue of political stability played a role in the definition of the Bundesbank's actual status as an independent institution. In general, from what has been said about the making of the Bundesbank Law of 1957, it follows that the determinants of the evolution of the legal status of Germany's central bank were also those governing its actual independence between 1950 and 1957. This is a direct consequence of the fact that, contrary to what one is lead to expect from the stereotype of the independent German central bank, there was no early national consensus on the desired status of the Bundesbank. Both its actual and the legal independence were in question before 1957 and only then the bank's legal position can be safely interpreted as mirroring the degree of actual autonomy it had shown in earlier conflicts with the government. Surveying the factors contributing to this development, it becomes clear that many of the arguments discussed in the present literature on central bank independence are valid in this context as well. But it is useful to note some modifications. First, institutional time path dependencies (and sheer luck) played a role in the evolution of independence. Still, it was the unresolved issue of federalism (rather than the insight in the trade-off between the short and the long term advantages of independence) that helped the Bundesbank to save the autonomy against German authorities it had been granted by the Allies in 1948. Second, the Bundesbank not only passively relied on public support for its independent policies and the matching legal provisions, it was also a very active political player that successfully influenced public opinion. Third, in the evolution of the Bundesbank Law of 1957 personal and policy (in)dependence were considered close substitutes. This observation should caution reliance on measures of legal central bank independence alone, because the consequences of government nominations to the central bank Council can only be evaluated looking at actual behaviour of the nominees.

\section{Policy conflicts between the federal government and the Bundesbank in the 1960 s}

Broadly speaking, two kinds of conflicts have occurred between the federal government and the Bundesbank after 1957. First, there were some clashes over exchange rate policy. The revaluations of the Dmark in 1961 and 1969 come to mind. ${ }^{15}$ Second, conflicts arose when the stances of fiscal and monetary policy differed. For instance, in case of increasing deficits the government often disliked interest rates being increased. Especially, during periods of restrictive monetary policy the Bundesbank has been criticized; the more stringent policy turned, the harsher the critique was. At the same time, the Bundesbank in such a situation often criticized government for being too lax, and it argued that, 
therefore, monetary policy had to be more restrictive than would be the case if government were more stringent. ${ }^{16} \mathrm{We}$ will discuss these conflicts in turn.

The German constitution places decisions about re- or devaluation in the realm of the government. This does not mean, however, that the Bundesbank had no interest in influencing these decisions. The Bundesbank correctly viewed exchange rate policy as a means to effect domestic inflation within the Bretton Woods system after the Dmark became fully convertible in 1959. The first occasion the bank's ability was tested arose in the in 1960/61. At the time, Germany was wrestling both with internal and external imbalances. Inflation was rising, while at the same time the surplus of the current account increased. Under full convertibility of the Dmark it was hard to tackle both problems simultaneously, without changing the exchange rate or introducing some kind of capital controls. The government had been divided on the issue of a revaluation for a long time. Whereas the minister of Economic Affairs, Erhard, was in favour, Chancellor Adenauer - and with him the majority of the conservative party and most industrial interest groups - opposed a revaluation. Similarly, the majority of the Zentralbankrat initially opposed revaluation. However, when monetary policy measures taken in June 1960 (a discount rate increase to 5 percent, increase of minimum reserves and a reduction in rediscount quotas) proved not enough to stem inflationary pressures, the Bundesbank changed course (Berger, 1995). According to Emminger (1977), it was only then that the Bundesbank accepted that it was impossible to reach internal stability and at the same time keep the exchange rate stable. This, of course, does not come as a surprise, since by raising interest rates the Bundesbank also increased interest differentials vis-a-vis the US, thereby triggering capital inflows. Consequently, the Bundesbank switched to a monetary policy directed towards stabilising the balance of payments, i.e. it reduced interest rates. In addition, the Bundesbank sharply criticized the government for not restricting fiscal policy enough to help the bank securing domestic price stability. Although the government took some measures, they were apparently not sufficient to cool down the economy and reduce inflation. The policy stance of the Bundesbank raised objections from government. "This was one of the rare instances when a Bundesbank decision involving relaxation encountered open resistance from the government. [But]....the manifest ineffectiveness of monetary policy against domestic overheating finally forced the government to act on the external front" (Emminger, 1977, p. 15). So, in this interpretation the policy of the Bundesbank forced government to revalue the Dmark. When government finally publicly took the initiative for the Dmark revaluation, the Zentralbankrat supported this move in its meeting of March 3, $1961 .{ }^{17}$ Still, the official statement made it very clear that the initiative for the revaluation came from Bonn.

A very similar development took place in 1969, albeit that positions of the various players were somewhat different. Although it had publicly opposed such a measure earlier (Schenkluhn, 1985), in September 1968 the Bundesbank advised a revaluation in view of the differences between inflationary developments in Germany and those abroad and the position of the balance of payments. However, both the minister of Economic Affairs, Schiller (12/1966-07/1972, SPD) and Chancellor Kiesinger (01/1966-10/1969, CDU) rejected this view (Emminger, 1977). During a conference of finance ministers and central bank governors of the Group of Ten in Bonn, the Zentralbankrat sent a telex message to the government, which was made public ${ }^{18}$, in which it repeated its view about a revaluation. Under the influence of ongoing capital inflows, Schiller changed his mind and in March 1969 expressed himself in favour of a revaluation. However, Kiesinger and, especially, the minister of Finance, Franz Josef Strauß (12/1966-10/1969, CSU), still very much opposed this realignment. This issue led to a 
conflict in the coalition. During the election period, the issue was very important. After the elections in September 1969 a new coalition of social democrats and liberals came into power and this new government decided in favour of a revaluation of $9.3 \%$ on October, 24, 1969. Although these developments led to some discussion whether independence of the Bundesbank should be restricted, things remained as they were.

The revaluation helped only temporarily. In April 1971 again some speculative attacks occurred, which led the Bundesbank to reduce the discount rate by 1 percentage point. A debate took place whether the Dmark should float. A majority of the Zentralbankrat (11 out of 18) supported Bundesbankpresident Klasen in his rejection of this option (Schenkluhn, 1985), but in May 1971 the government decided to let the Dmark float. Whereas Schiller liked the Dmark to rise by 5-6\%, Klasen preferred the Dmark to stick to its parity, but the majority of the Zentralbankrat supported the view of Schiller in its meeting of May, 18/19 (Schenkluhn, 1985). In the Smithsonian Agreement of December 1971 it was decided that the Dmark would be revaluated vis-a-vis the dollar by 13.6 percent (Emminger, 1977).

The Smithsonian Agreement did not last for long. Speculative attacks in 1972 produced a new conflict between the government, or more precisely, Schiller, and the Bundesbank, as both had different opinions as to how these attacks should be counteracted (see Holtfrerich, 1988 for further details). The president of the Bundesbank convinced the rest of the cabinet that his favoured measure should be applied. Since Schiller was outvoted, he resigned. As Holtfrerich (1988, p. 148) put it: "Thus, the independent Bundesbank, by law obliged to advise the government in currency matters, had contributed to the downfall of the cabinet's strongest member...". Schiller was replaced by Helmut Schmidt (07/1972-05/1974, SPD). In 1973 Schiller proved to be right, when the Bretton Woods system finally brook down. The Bundesbank gave priority to an anti-inflationary stance and increased discount rates in three steps to 7 percent in June 1973.

As pointed out above, not only conflicts about exchange rate policies occurred, but there were also some clashes on the stances of monetary and fiscal policy. Take, for instance, 1965, during which the federal government under Erhard increased public outlays significantly. According to Holtfrerich (1988), the government under the new chancellor Erhard hoped to win the elections of September 1965 with this spending spree. So, it is clear that the federal government would not like higher interest rates, but that is what it got. Exploiting an increase in US interest rates, the Bundesbank raised its discount rate from 3\% to 3.5\% in January 1965, after it had not changed the discount rate since 1961 (figure 1) ${ }^{19}$ As explained in the Monthly Report of January 1965, this increase was deemed necessary to stem rising inflation due to expansionary domestic demand. Right from the beginning, it became clear that the government did not appreciate the monetary policy stance. In the official minutes of the meeting of the Zentralbankrat at January 21, 1965, the minister for Economic Affairs Kurt Schmücker (10/1963$11 / 1966, \mathrm{CDU})$ wondered whether the increase of the discount rate at the time would be wise, since it might strengthen parliamentary opposition towards a proposal concerning the "Kuponsteuergesetz". ${ }^{20}$ Still, if the Bundesbank were to decide in favour of raising the discount rate "the government would refrain from using its (suspensive) veto power against this change". ${ }^{21}$ During the same meeting the Undersecretary (Staatsekretär) of the Ministry of Finance pointed out that the Treasury would favour not raising the discount rate, at least not presently. 
However, starting from August 13th, the discount rate was again raised by 0.5 percentage points, as was the Lombard rate. During the decisive meeting of the Zentralbankrat the Undersecretary of Economic Affairs expressed the government's worries about the consequences of raising the discount rate in terms of higher capital rates. The opposition of the government may have impressed some members of the Zentralbankrat. While the rise of the discount rate in January had been decided with just four abstentions, the vote now was close: ten members voted in favour and nine against a higher discount rate. ${ }^{22}$ In another repetition of the by now well-known pattern of monetary restriction and criticism of the government, the Bundesbank hurried to inform the German public that the government was responsible for its latest contractionary move. To motivate the further increase of the interest rate the Bundesbank pointed to the overheated economy as well as to the deficit on the trade balance. Although it was acknowledged that such a deficit could contribute to restoring equilibrium "it is important to assure that these effects are not compensated by an increase in credit demand, be it from the side of private firms or the public sector" (Monthly Report, August 1965, p. 5).

In its September 1965 issue of the Monthly Report (pp. 6-7), the Bundesbank stated that the worsening position of the public finances was not due to cyclical factors, but a direct consequence of policy measures. Whereas income taxes were reduced from January 1965 onwards, the outlays of the federal government increased substantially in the first half of the year; especially transfers to households were raised. A similar complaint was made in the October issue, where it is argued that fiscal policy undermined the effect of monetary policy: "The fact that the public sector has not behaved "anticyclical" at all this year - on the contrary, it significantly increased excessive domestic demand has undermined the effects of monetary policy (p.5). It also stated (p.27) that the plans for 1966, as far as known, "are not enough to restore equilibrium". The critique of the Bundesbank hardly influenced fiscal policy. In fact, the Bundesbank stood virtually alone in its critique of the expansionary fiscal stance. Despite rising inflationary expectations, voters and interest groups alike were hard to convince that the government's election promises would not eventually be financed by the high growth rates of the German economy (Schenkluhn, 1985). Consequently, at its meeting of May, 26, 1966 the Zentralbankrat decided - now unanimously - to increase the discount rate to 5\%, the Lombard rate was raised from 5 to 6,25\%. ${ }^{23}$ In the Monthly Report of May 1966, the motivation given for this increase is that short-term interest rates were higher than the official rates: "With unchanged Bundesbank interest rates central bank credit would have become the cheapest source of new money" (p.3). At the time, the Bundesbank did not observe any signs that financial stability had improved; prices and wages, for instance, kept increasing, so that there were "no signs in the economy that would allow the conclusion that the contractionary monetary stance should be changed" (p. 4).

However, in the course of 1966 a recession set in. Although various authors ascribe this recession to the policy of the Bundesbank (see e.g. Giersch et al., 1992), Emminger (1977) argues that the monetary measures were relatively mild and that other factors (balance of payments deficit and cost increases which led to a profit squeeze) had a much greater dampening effect on economic activity. ${ }^{24}$ Still, government requested a relaxation of monetary policy (Caesar, 1981, p. 189). According to various observers (including Holtfrerich, 1988) restrictive monetary policy and the following recession led to the downfall of Erhard ${ }^{25}$ and the formation of a new coalition between social democrats and christian democrats under Kiesinger (the so-called Grand Coalition) in November 1966. Much to the relief of the Bundesbank, the new coalition quickly agreed on ways to cut Erhard's election inspired expenditure plans. This brought not, however, a better relationship with the government. In his 
inaugural speech Kiesinger demanded that the Bundesbank eased monetary policy (Holtfrerich, 1988), which it did not immediately. Only in January 1967, with both monetary and real business indicators for the first time in post-war history clearly pointing towards a recession, the discount rate was reduced to $4.5 \%$. According to the minutes of the meeting of the Zentralbankrat January, 5, 1967 there was still a debate within that body how much the discount rate should be reduced in the light of uncertainties concerning wage developments and government policy. Emminger, for instance, argued in favour of a reduction of only 0.5 percentage point which would be enough in terms of a signal, while some others favoured a decline of 1 percentage point. But the majority of members agreed that, if the bank would refrain from at least a marginal cut in the interest rate, it might be "blamed for the unavoidable recession all alone". ${ }^{26}$

At the meeting of the Zentralbankrat of February, 16 the new minister of Economic Affairs, Karl Schiller was present and he argued that Germany was under international pressure to reduce interest rates because of the (temporary) increase in Germany's balance of payments surplus in early 1967. He explicitly asked for a reduction of $3 / 4$ percentage point, but only two members of the council agreed with him, so that the discount rate was reduced to 4 percent. ${ }^{27}$ In the Monthly Report of February it was argued that Germany no longer had an external imbalance and that the inflationary pressures were kept in hold. Indeed, the "Bundesbank thought it necessary to stimulate investment activity through monetary measures" (p. 4).

In April the discount rate was further reduced to 3.5 percent. ${ }^{28}$ Another reduction to 3 percent was announced after the meeting of the Zentralbankrat of May, 11. During this meeting Emminger argued in favour of this reduction as it should further support expansionary fiscal policy, ${ }^{29}$ to which the new government had switched in order to stimulate the economy (Schenkluhn, 1985). So it seemed that monetary and fiscal policy were both on an expansionary track. Still, in April 1967 Schiller publicly criticized the slow response of the Bundesbank to the worsened economic conditions at the time (Ceasar, 1981). Although it publicly supported the fiscal stance, in its Monthly Report of June 1967 the Bundesbank expressed doubts whether the "planned deficit financing of the public sector exceeds the level which would be in accordance with a stability oriented policy" (p.5). Although the Bundesbank did not consider this to be the case under the circumstances of the time, it warned that in case of increasing demand for credits from the private sector it would be the task of fiscal policy to reduce deficit spending (p. 6). Indeed, at the end of 1968 there were signs of possible overheating, which were the overture in the debate about revaluation of the Dmark as outlined above. After the revaluation, the Bundesbank stuck to its restrictive stance and raised the discount rate in four consecutive steps to 6 percent, while the Lombard rate was even forced up to 9 percent in December 1969. Fiscal policy in that year was sometimes criticized by Bundesbank officials. Emminger argued, for instance, in favour of a more restrictive fiscal policy stance, but the new Bundesbank president Klasen also saw the danger of such restrictive policies (Schenkluhn, 1985).

\section{Conclusions}

The Bundesbank is often regarded as a very independent central bank. This does not imply, however, that it operates in a political vacuum. In this paper we have analysed certain periods in the history of the Bundesbank concentrating on the determinants of central bank independence. It is concluded that 
many determinants outlined in the literature (notably public opinion and political instability) played indeed a role in the making of the Bundesbank Law of 1957. Still, it was mainly the unresolved issue of federalism that helped the Bundesbank to save its legal autonomy originally granted by the Allies in 1948.

The law has not been changed since its introduction in 1957. This may be interpreted differently. Either the government believed that the balance between benefits and costs of having an independent central bank did not fundamentally change, or the policymakers believed that no matter what the law says, government could have its way. Our analysis of the conflicts between the Bundesbank and the federal governments over monetary policy suggest that if a conflict concerned interest rate policy, the Bundesbank always got its way. Even with respect to exchange rate policy, which is primarily in the realm of the federal government, the position of the Bundesbank often prevailed. So it is clear that the second possible interpretation is not supported by our results.

We also made it clear that the theory on the determinants of central bank independence overlooks that very often the government and the Bundesbank were not two monolithic entities, that had different views about policy. In fact, both the government and the Bundesbank were often divided in themselves. This generated opportunities for the Bundesbank majority to find allies within government. This is very clear with respect to the 1955/56 conflict, but also on other occasions (like the revaluation of 1961). Indeed, by exploiting such room for manoeuvre the Bundesbank exerted much influence, also on decisions regarding exchange rate policy, which are primarily in the realm of government. 


\section{References}

Andersen, T.M. and F. Schneider (1986), Coordination of Fiscal and Monetary Policy under Different Institutional Arrangements, European Journal of Political Economy, 169-191.

Balkhausen, D. (1992), Gutes Geld und schlechte Politik. Der Report über die Bundesbank, Düsseldorf.

Berger, H. (1995), Stabilization Policy During the Wirtschaftswunder: Scope of Action and Behavioral Patterns of the Bundesbank and the Government (in German), Ph D Thesis, University of Munich.

Berger, H. (1996), The Bundesbank's Path to Independence. Evidence from the 1950s, Münchener Wirtschafswissenschafliche Beiträge, Nr. 96-09; forthcoming in: Public Choice.

Berger, H. and U. Woitek (1996), Searching for Political Business Cycles in Germany, forthcoming in: Public Choice.

Berger, H. and U. Woitek (1997), How Opportunistic are Partisan German Central Bankers? Evidence on the Vaubel Hypothesis, forthcoming in: European Journal of Political Economy.

Berger, H. and A. Ritschl (1995), Germany and the Political Economy of the Marshall Plan, 194752: a Re-revisionist View, in: B. Eichengreen (ed.), Europe's Post-war Recovery, Cambridge, Cambridge University Press, pp. 199-245.

Blessing, K. (1967), Finanzpolitik und Währungspolitik, in: A. Müller-Armack and H.B. Schmidt (eds.), Wirtschaft- und Finanzpolitik im Zeichen der Socialen Marktwirtschaft, Stuttgart, Seewald, pp. 273-279.

Buchstab, Günter (Ed.) (1990), Die Protokolle des CDU-Bundesvorstandes, Band 2: 1953-1957, Adenauer: "Wir haben wirklich etwas geschaffen", Düsseldorf, Droste.

Bundesgesetzblatt (various issues).

Ceasar, R. (1981), Der Handlungsspielraum von Notenbanken, Baden-Baden, Nomos Verlagsgesellschaft.

Cukierman, A. (1992), Central Bank Strategy, Credibility, and Independence, Cambridge: MIT Press.

Cukierman, A. (1994), Commitment through Delegation, Political Influence and Central Bank Independence, in: J.A.H. de Beaufort Wijnholds, S.C.W. Eijffinger and L.H. Hoogduin (eds.), A Framework for Monetary Stability, Dordrecht/Boston/London, Kluwer Academic Publishers, 5574.

Cukierman, A. (1996), The Economics of Central Banking, forthcoming in: H. Wolf (ed.), Macroeconomic Policy and Financial Systems, London, The MacMillan Press. 
Debelle, G. and S. Fischer (1995), How Independent Should a Central Bank Be?, in: J.C. Fuhrer (ed.), Goals, Guidelines and Constraints Facing Monetary Policymakers, Federal Reserve Bank of Boston, Conference Series No. 38, Boston, 195-221.

Doyle, C. and M. Weale (1994), Do We Really Want an Independent Central Bank?, Oxford Review of Economic Policy, 10, 61-77.

Eijffinger, S.C.W. and J. de Haan (1996), The Political Economy of Central-Banking, Princeton Special Papers in International Economics, No. 19.

Emminger, O. (1977), The D-Mark in the Conflict between Internal and External Equilibrium 194875, Princeton Essays in International Finance, No. 122.

Forder, J. (1996), On the Assessment and Implementation of 'Institutional' Remedies, Oxford Economic Papers, 48, 39-51.

Frey, B. and F. Schneider (1981), Central Bank Behaviour. A Positive Empirical Analysis, Journal of Monetary Economics, 7, 291-315.

Gesetz- und Verordnungsblatt des Wirtschaftsrates des Vereinigten Wirtschaftsgebiets (1948).

Giersch, H., K-H. Paque and H. Schmieding (1992), The Fading Miracle. Four decades of market economy in Germany, Cambridge, Cambridge University Press.

Grilli, V., D. Masciandaro and G. Tabellini (1991), Political and Monetary Institutions and Public Financial Policies in the Industrial Countries, Economic Policy, No. 13, 341-392.

Haan, J. de and G.J. van 't Hag (1995), Variation in Central Bank Independence across Countries: Some Provisional Empirical Evidence, Public Choice, 85, 335-351.

Haan, J. de (1995), Why Does Central Bank Independence Yield Lower Inflation?: A Taxonomy of Arguments and Empirical Evidence, Working Paper, Department of Economics, University of Groningen.

Haan, J. de (1996), The European Central Bank: Independence, accountability and strategy. A review, forthcoming in: Public Choice.

Hentschel, V. (1988), Die Entstehung des Bundesbankgesetzes 1949-1957. Politische Kontroversen und Konflikte, Parts 1 and 2, Bankhistorisches Archiv, 3-31 and 79-115.

Hagemann, W. (1984), Von der Ordnungs- zur Konjunkturpolitik. Zur Funktions-entwicklung staatlicher Wirtschaftspolitik in Westdeutschland - ein Beitrag zur Frage nach dem Verhältnis von Ökonomie und Politik -, Essen, Eule.

Historisches Archiv der Deutschen Bundesbank

Holtfrerich, C.L. (1988), Relations between Monetary Authorities and Governmental institutions: The case of Germany from the 19th Century to the Present, in: G. Toniolo (ed.), Central Banks' Independence in Historical Perspective, Berlin, Walter de Gruyter, pp 105-159. 
Issing, O. (1993), Unabhängigkeit der Notenbank und Geldwertstabilität, Akademie der Wissenschaften und der Literatur, Abhandlungen der Geistes- und Sozialwissenschaflichen Klasse, Jahrgang 1993, nr. 1.

Kane, E.J. (1980), Politics and Fed Policymaking: The More Things Change, the More They Remain the Same, Journal of Monetary Economics, 6, 199-211.

Koerfer, D. (1988), Kampf ums Kanzleramt, Erhard und Adenauer, Stuttgart, DVA, 2nd Edition.

Marsh, D. (1992), The Bundesbank. The Bank That Rules Europe, London, Heinemann.

Moser, P. (1994), The Supply of Central Bank Independence, University of St.Gallen Discussion Paper, 9501.

Posen, A.S. (1993), Why Central Bank Independence Does Not Cause Low Inflation: There Is No Institutional Fix for Politics, in: R. O'Brien (ed.) Finance and the International Economy: 7, Oxford, Oxford University Press.

Posen, A.S. (1995), Declarations Are Not Enough: Financial Sector Sources of Central Bank Independence, in: NBER Macroeconomics Annual 1995.

Riedl, A. (1992), Liberale Publizistik für Soziale Marktwirtschaft, Die Unterstützung der Wirtschaftspolitik Ludwig Erhards in der Frankfurter Allgemeinen Zeitung und der Neuen Züricher Zeitung 1948/49 bis 1957, Regensburg, Roderer.

Rogoff, K. (1985), The Optimal Degree of Commitment to an Intermediate Monetary Target, Quarterly Journal of Economics, 110, 1169-1190.

Schenkluhn, B. (1985), Konjunkturpolitik und Wahlen, Bergisch Gladbach, Verlag Josef Eul.

Schwarz, H-P. (1991), Adenauer, Der Staatsmann: 1952-1967, Stuttgart, DVA.

Vaubel, R. (1997), The Bureaucratic and Partisan Behaviour of Independent Central Banks: German and International Evidence, forthcoming in: European Journal of Political Economy. 
1. Die Zeit, November, 8, 1996, p. 3.

2. The survey was undertaken by the Mannheim Institute for Praxis Oriented Social Research and is cited in Balkhausen (1992).

3. This means that the central bank is more averse to inflation than the government, in the sense that the bank places a greater weight on the loss from inflation than the government does.

4. The value of the codings of various legal central bank independence measures increases (i.e. assign a higher degree of independence), the more stringent the objective of price stability is, i.e. the less goal independent the central bank in fact is. The reason for this is that the indices under discussion suppose to measure the 'conservative bias' of the central bank.

5. Gesetz über die Errichtung der Bank deutscher Länder (Law on the Establishment of a Bank deutscher Länder), February, 14, 1948, Beilage Nr. 3 zum Gesetz- und Verordnungsblatt des Wirtschaftsrates des Vereinigten Wirtschaftsgebiets, p. 1.

6. Übergangsgesetz zur Änderung des Gesetzes über die Errichtung der Bank deutscher Länder (Transformation Law on the Change of the Law on the Establishment of a Bank deutscher Länder), August, 10, 1951, Bundesgesetzblatt, Teil I, p. 509.

7. Gesetz über die Verteilung des erzielten Reingewinns der Bank deutscher Länder in den Geschäftsjahren 1950 und 1951 (Law on the Distribution of Bank deutscher Länder NetProfits in the Business-Years 1950 and 1951), August, 10, 1951, Bundesgesetzblatt, Teil I, p. 510.

8. For the quote from the Bundesbank Council see Berger (1995, p. 243). The Deutsche Zeitung, August, 6, 1955, for instance, printed an article titled "Alarm for Stabilisation Policy".

9. For a detailed analysis of the government's stabilisation policy during this period see Berger (1995, pp. 123-69). As a matter of fact, the years of conservative governments between 1949 and 1965 are the only subperiod of German postwar history during which federal fiscal policy followed a clear cut, statistically significant political business cycle pattern (ibid., Table 17).

10. Gesetz über die Deutsche Bundesbank (Law on the Deutsche Bundesbank), July, 30, 1957, Bundesgesetzblatt, Teil I, p. 745.

11. See Bundesbank (Monthly Report, August 1957, pp. 3-9) for a detailed analysis of the changed legal status of the German central bank. Also, the government's suspensive veto was extended from 8 to 14 days (par. 13). This change was not considered as very important.

12. Actually the replacement was considered a fact even before the Bundesbank Law was enacted (July, 26, 1957) and long before the elections were held (September, 15, 1957). See the discussions of the Central Bank Council July, 10, 1957 (Historisches Archiv der Deutschen Bundesbank (HADB), BdL/BBK-2/234-250, pp. 8-9). After the election Adenauer also took the opportunity to nominate a new Minister of Finance. Reluctantly Schäffer was transferred to the Ministry of Legal Affairs (10/1957-11/1961). Erhard's position changed to the positive, however. He became Vice-Chancellor. See Koerfer (1988) and Schwarz (1991). 
13. See Blessing's inaugural speech on January, 7, 1958 (HADB, B 330/136). In August 1959 there were press reports that "Bonn" already felt sorry about installing Blessing (communication between Blessing and the Ministry of Commerce (HADB, B 330/245)).

14. See Berger (1995, Table 18) for the Council's voting results on discount rate changes in this period.

15. Another conflict about exchange rate policy occurred at the end of the 1970s and is therefore not analysed in any detail in the present paper. Chancellor Schmidt had taken the initiative, together with the French president Giscard d'Estaing, to create the European Monetary System (EMS). The Bundesbank, having in mind the difficulties it envisaged under the final years of the Bretton Woods system, was initially not very enthusiastic about these plans. According to Marsh (1992), Schmidt, who was then chancellor, threatened during a visit to the Zentralbankrat that he might propose to change the independent status of the Bundesbank if it would oppose his plans.

16. As Bundesbankpresident Blessing (1967, p. 273) put it: "Over the years, in the concert of stabilization policy fiscal policy has always caused dissonances. At the few occasions it hit the right tone this happened by accident."

17. $H A D B, \mathrm{~B} 330 / 175 \mathrm{II}$.

18. It is not clear who is responsible here. Marsh (1992) suggests that the Bundesbank made the telex public, whereas Emminger (1977, p. 25) states that "through an indiscretion in Bonn, the telex was brought to the attention of the public".

19. In mid 1964 the Bundesbank had already increased the minimum requirements in order to reduce bank liquidity. Starting on January, 21 the Lombard rate was also increased from $4 \%$ to $4.5 \%$.

20. This was a proposal to extend German capital income taxation to foreigners in order to lower interest rate induced capital inflows from abroad. The law was enacted March, 25, 1965.

21. Council meeting January, 21, 1965, $H A D B$, B 330/437, p. 6.

22. Meeting August, 8, 1965, $H A D B$, B 330/443 II, pp. 13-14.

23. $H A D B$, B $330 / 451$, p. 8

24. However, in the Monthly Report of August, 1966, the Bundesbank claims that "the relaxation of the cyclical situation in Germany is to a considerable extent the result of the restrictive course of monetary policy of the Bundesbank..." (p. 4).

25. The coalition of christian democrats and liberals broke down due to diverging views of the coalition partners how to redress the public finances.

26. $H A D B$, B $330 / 458$, pp. 9-12

27. $H A D B, \mathrm{~B} 330 / 459$, p. 11. 
28. A proposal to reduce the discount rate by a full percentage point was rejected with 9 votes against and 7 in favour (including Emminger). See $H A D B, \mathrm{~B} 330 / 461$.

29. $H A D B, \mathrm{~B} 330 / 461$, p. 6. In a real Keynesian way it is argued in the Monthly Report of May (p. 7) that "If in this situation the decline in the demand for credit from the private sector would not have been compensated by increased demand for funds by the government (and from abroad) a deflationary trend could not have been avoided." 
Figure 1

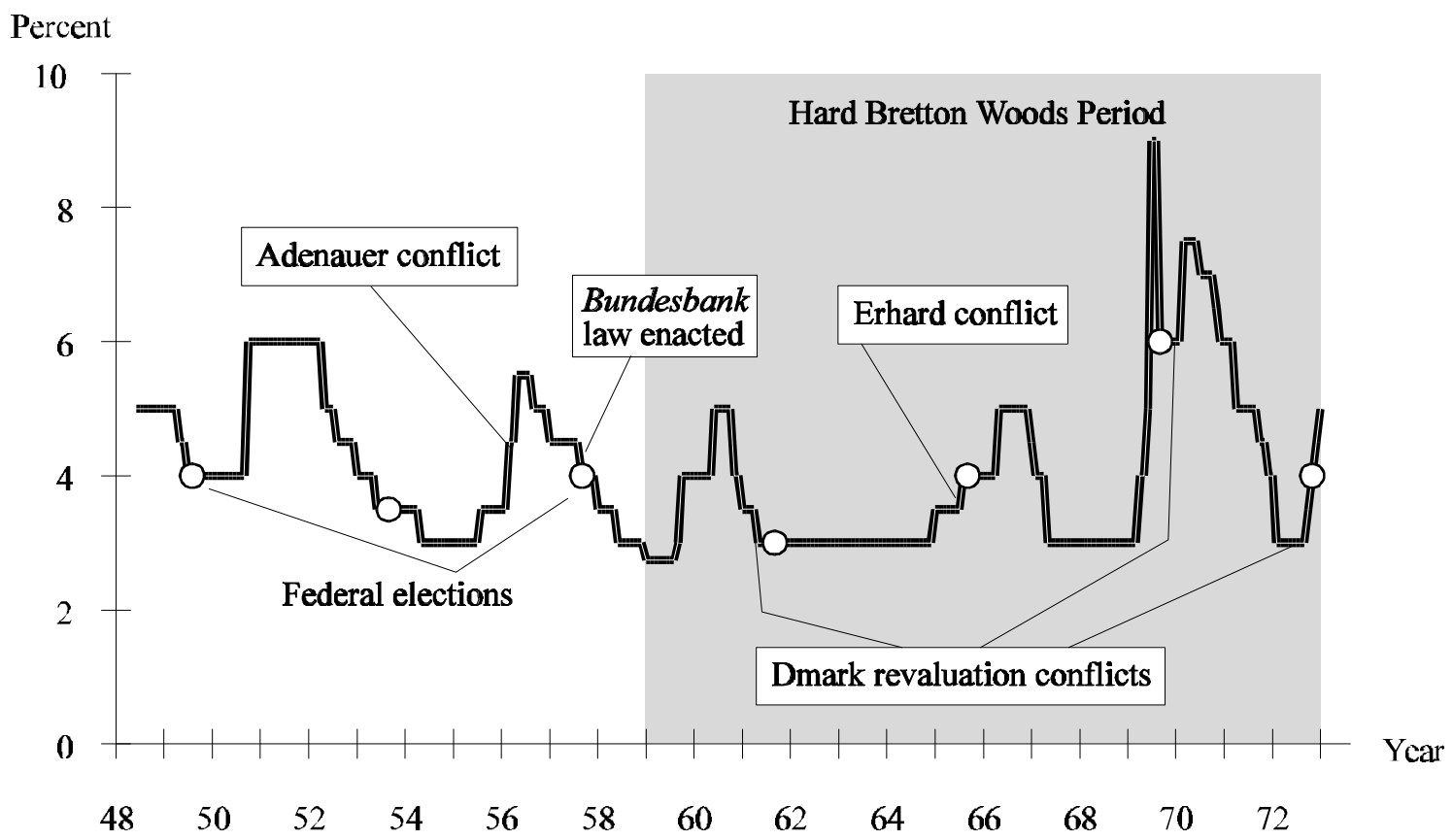

